\title{
Os desafios da gestão do SUS sob a ótica de gestores municipais de saúde
}

\author{
Amanda Morais Polati, David Geraldo Santos Oliveira, Vanessa Souza Amaral, Adélia Contiliano \\ Expedito, Matheus Augusto Soares de Resende, Deíse Moura de Oliveira
}

\begin{abstract}
Resumo
A descentralização é um dos princípios que remete a avanços significativos na construção do Sistema Único de Saúde (SUS), pois rompe com o modelo centralizado na assistência e redistribui recursos e responsabilidades entre os entes federativos, passando a gestão do Sistema de Saúde ser uma responsabilidade compartilhada pela União, Estados e Municípios. Tal avanço descortina por outro lado inúmeros desafios, muitos deles inscritos no âmbito municipal, em que os gestores assumem papel fundamental para que as ações e serviços ofertados estejam em consonância com as necessidades particulares de cada região. Compreender os desafios inscritos na gestão do SUS sob a perspectiva dos gestores municipais de saúde de uma microrregião de saúde de Minas Gerais. Pesquisa descritiva, de natureza qualitativa, que tem como participantes os gestores municipais de saúde de uma microrregião de saúde da Zona da Mata de Minas Gerais, composta por nove municípios. A coleta de dados iniciou-se no mês de junho de 2016, por meio de um roteiro de entrevista com questões abertas. Os dados estão sendo analisados à luz de Bardin e serão interpretados e discutidos em consonância com a literatura pertinente à temática. Cabe ressaltar que a coleta de dados encontra-se ainda em andamento, sendo realizada uma análise parcial dos dados coletados até o momento. O projeto foi aprovado pelo Comitê de Ética em Pesquisa com Seres Humanos da Universidade Federal de Viçosa, inscrito sob o Parecer $n^{\circ} 1.147 .443$. A pesquisa permite preliminarmente evidenciar que os desafios inscritos na gestão do SUS estão relacionados ao subfinanciamento -repasse defasado e aquém do contratualizado, implicando em sobrecarga do ente municipal - ; à morosidade do sistema - em especial no tocante à marcação de cirurgias eletivas -; à gestão dos recursos humanos - relacionada à desqualificação de profissionais com perfil para atuar no SUS e, por outro lado, à precarização do trabalho em saúde- ; à ausência de autonomia do gestor - com ênfase para a impossibilidade de manejar os recursos do fundo municipal de saúde -; ao incipiente controle social - marcado pela ausência de participação da população na saúde - e a deficiente formação do próprio gestor para gerir um sistema complexo como o SUS - evidenciado no fato de a maioria dos gestores não terem experiência prévia no setor saúde. Conclusão: ao conhecer os desafios enfrentados pelos gestores municipais de saúde espera-se que este estudo produza evidências que auxiliem pesquisadores, profissionais de saúde e os próprios gestores do SUS a reconhecer os nós críticos que permeiam a municipalização e a (re)pensar possíveis caminhos para superá-los.
\end{abstract}

Descritores: Sistema Único de Saúde; Gestão em Saúde; Pesquisa Qualitativa. 